PREPARED FOR THE U.S. DEPARTMENT OF ENERGY, JNDER CONTRACT DE-AC02-76-CHO-3073

PPPL-3129

PPPL-3129

UC-426

MEASUREMENTS OF ENERGETIC CONFINED ALPHAS

AND TRITONS ON TFTR

BY

S.S. MEDLEY, R.V. BUDNY, D.K. MANSFIELD, ET AL.

AUGUST 1995
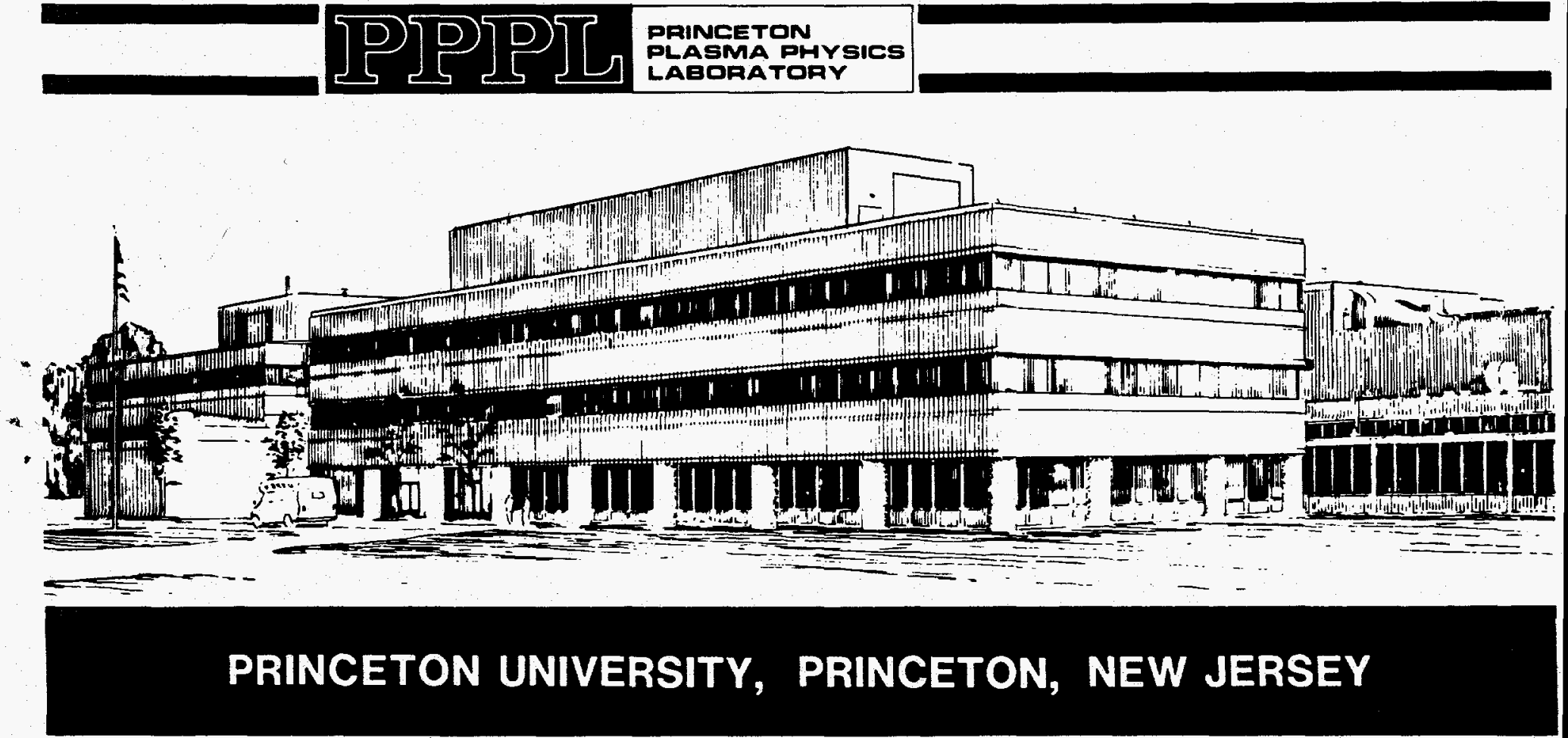


\section{NOTICE}

This report was prepared as an account of work sponsored by an agency of the United States Government. Neither the United States Government nor any agency thereof, nor any of their employees, makes any warranty, express or implied, or assumes any legal liability or responsibility for the accuracy, completeness, or usefulness of any information, apparatus, product, or process disclosed, or represents that its use would not infringe privately owned rights. Reference herein to any specific commercial produce, process, or service by trade name, trademark, manufacturer, or otherwise, does not necessarily constitute or imply its endorsement, recommendation, or favoring by the United States Government or any agency thereof. The views and opinions of authors expressed herein do not necessarily state or reflect those of the United States Government or any agency thereof.

\section{NOTICE}

This report has been reproduced from the best available copy.

Available in paper copy and microfiche.

Number of pages in this report: 7

DOE and DOE contractors can obtain copies of this report from:

Office of Scientific and Technical Information

P.O. Box 62

Oak Ridge, TN 37831 ;

(615) $576-8401$.

This report is publicly available from the:

National Technical Information Service

Department of Commerce

5285 Port Royal Road

Springfield, Virginia 22161

(703) $487-4650$ 


\section{DISCLAIMER}

Portions of this document may be illegible in electronic image products. Images are produced from the best available original document. 


\section{DISCLAIMER}

Portions of this document may be illegible in electronic image products. Images are produced from the best available original document. 


\title{
Measurements of Energetic Confined Alphas and Tritons on TFTR
}

\author{
S. S. Medley, R. V. Budny, D. K. Mansfield, M. H. Redi, A. L. Roquemore \\ Princeton Plasma Physics Laboratory, P. O. Box 451, Princeton, New Jersey 08543 USA \\ R. K. Fisher, H. H. Duong, J. M. McChesney, P. B. Parks \\ General Atomics, San Diego, California 92186 USA \\ M. P. Petrov \\ A. F. Ioffe Physical-Technical Institute, St Petersburg, 194021 Russia \\ N. N. Gorelenkov \\ TRINITI, Troisk 142092 Russia
}

\subsection{Introduction}

In a collaboration involving General Atomics, the A. F. Ioffe Physical-Technical Institute, and the Princeton Plasma Physics Laboratory, the energy distribution of the fast-confined alpha particles in DT experiments on TFTR is being measured by active neutral particle analysis using the ablation cloud surrounding an injected impurity pellet as the neutralizer[1]. Recent papers reported the first measurements of the energy distribution fast confined alpha particles[2] and examined the influence of magnetic field ripple and sawtooth oscillations on the behavior of the alpha energy spectra and radial density distributions[3]. This paper focuses on alpha and triton measurements in the core of quiescent TFTR discharges where the expected classical slowing down and pitch angle scattering effects are not complicated by stochastic ripple diffusion and sawtooth activity.

\subsection{Pellet Charge Exchange (PCX) Diagnostic and Data Analysis}

A toroidally extended ablation cloud forms around the pellet when it is injected into a plasma. A small fraction of the fusion alphas incident on the cloud are converted to helium neutrals as a result of electron capture processes. The escaping helium neutrals are mass and energy analyzed using a high energy $\left(0.5-4.1 \mathrm{MeV}\right.$ for $\left.{ }^{4} \mathrm{He}\right)$ neutral particle analyzer developed by the Ioffe Institute[4]. The neutral particle analyzer views the radially injected pellet from behind at a toroidal angle of $2.75^{\circ}$ to the pellet trajectory. Thus only near perpendicular energetic ions with velocities close to $\mathrm{v} \| / \mathrm{v}=0.048$ are detected by the $\mathrm{PCX}$ diagnostic. The radial position of the pellet as a function of time is measured using a linear photodiode array situated on the top of the vacuum vessel. By combining this measurement with the time dependence of the PCX signal, radially resolved fast ion energy spectra and density radial profiles can be derived with a radial resolution of $\sim 5 \mathrm{~cm}$. Further details on the PCX diagnostic have been presented elsewhere[5,6], including results obtained on the measurement of RF-generated energetic ion energy distributions.

By measuring of the energy distribution, $\mathrm{dn}_{\mathrm{o}} / \mathrm{dE}$, of helium neutrals escaping from the plasma, the energy distribution of the incident alpha particles, $\mathrm{dn}_{\alpha} / \mathrm{dE}$, can be determined using:

$$
\begin{aligned}
& \text { DISTRIBUTION OF THIS DOCUMENT IS UNLIMITED } \\
& \mathrm{dn}_{\alpha} / \mathrm{dE} \sim \mathrm{dn}_{\mathrm{o}} / \mathrm{dE}\left[\mathrm{F}_{\mathrm{o}}(\mathrm{E})\right]^{-1}
\end{aligned}
$$


where $\mathrm{F}_{\mathrm{o}}(\mathrm{E})$ is the equilibrium fraction of incident alphas neutralized in the cloud as a function of alpha energy. The value of $F_{0}(E)$ is obtained from modeling calculations [9]. The experimental data are compared with modeling results obtained with the TRANSP[7] Monte-Carlo Code and with a specially developed Fokker-Planck Post Processor (FPP) code. TRANSP follows the orbits of alphas as they slow down and pitch angle scatter by Coulomb collisions and takes into account the spatial and temporal distributions of background plasma parameters for each particular shot. Since the Monte-Carlo methods used in TRANSP give noisy results, we developed the FPP post processor code based on a numerical solution of the drift-averaged Fokker-Planck equation[8] which uses the pitch angle integrated alpha source distribution provided by TRANSP. The TRANSP and FPP calculations agree well when the modeling basis for both codes are applicable.

\subsection{Alpha Particle and Triton Measurements}

The alpha particle distributions measured by the PCX diagnostic can be influenced by the effects of classical slowing down and pitch angle scattering, toroidal magnetic field ripple and sawtooth activity. In order to separate the classical behavior from the other effects, PCX Li pellet active measurements of the slowing down alpha spectrum were obtained in the plasma core during a quiescent DT discharge (\#78607) and the triton spectrum from a similar DD discharge(\#78601) as shown in Fig. 1. Note that the error bars in Fig. 1 only reflect the statistical errors due to the counting statistics. The basic discharge parameters were: $\mathrm{R}=2.52 \mathrm{~m}, \mathrm{a}=0.8 \mathrm{~m}, \mathrm{~Pb} \sim 20 \mathrm{MW}$ with $I_{p}$ ramped down from 1.7 MA to 1.0 MA during the $1.3 \mathrm{~s}$ duration NBI pulse. The absolute scale for $\mathrm{dn} / \mathrm{dE}$ was derived from normalization of the PCX data with the TRANSP modeling results and was made only once for the alpha data as noted in the figure. The same normalization is used for the triton spectrum. Both the shape of the energy spectra as well as the ratio of the alpha-to-triton signal agree well with TRANSP simulations. This result corroborates the expectation that fusion generated alphas and tritons in the core of quiescent TFTR plasmas are well-confined and slow down classically.

In the TFTR DT experiments, pellets typically are injected 0.2 to $0.5 \mathrm{sec}$ after termination of neutral beam heating. This timing delay leads to deeper penetration of the

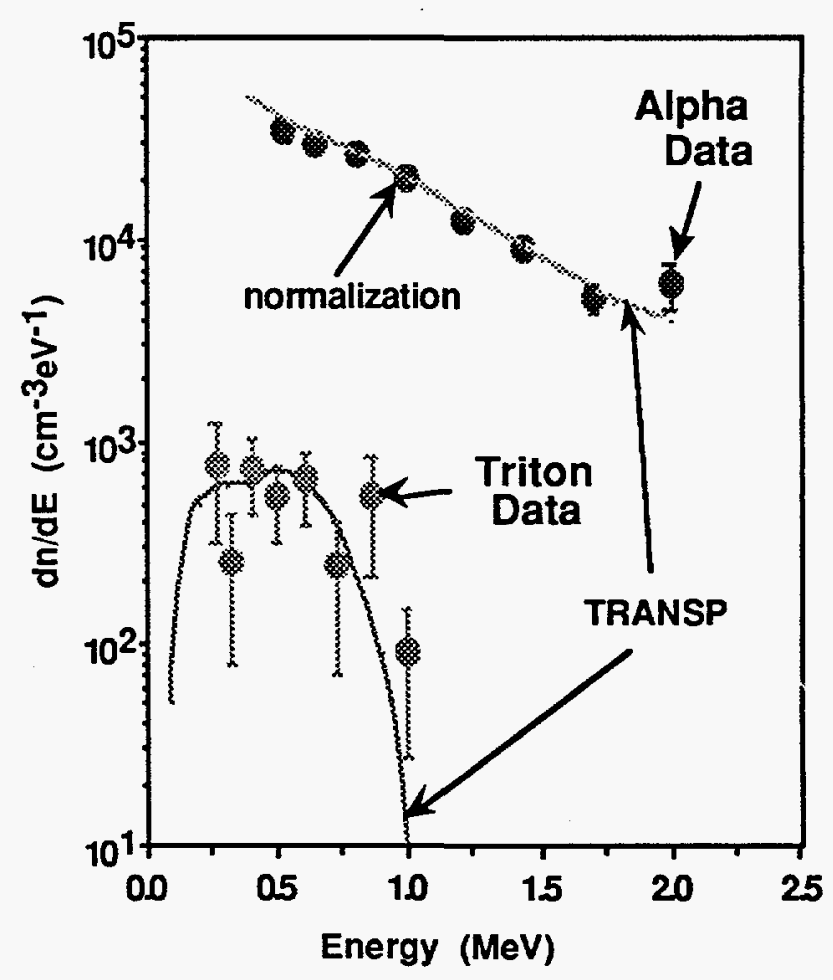

Fig. I Comparison of measured alpha and triton spectra with TRANSP simulation. 


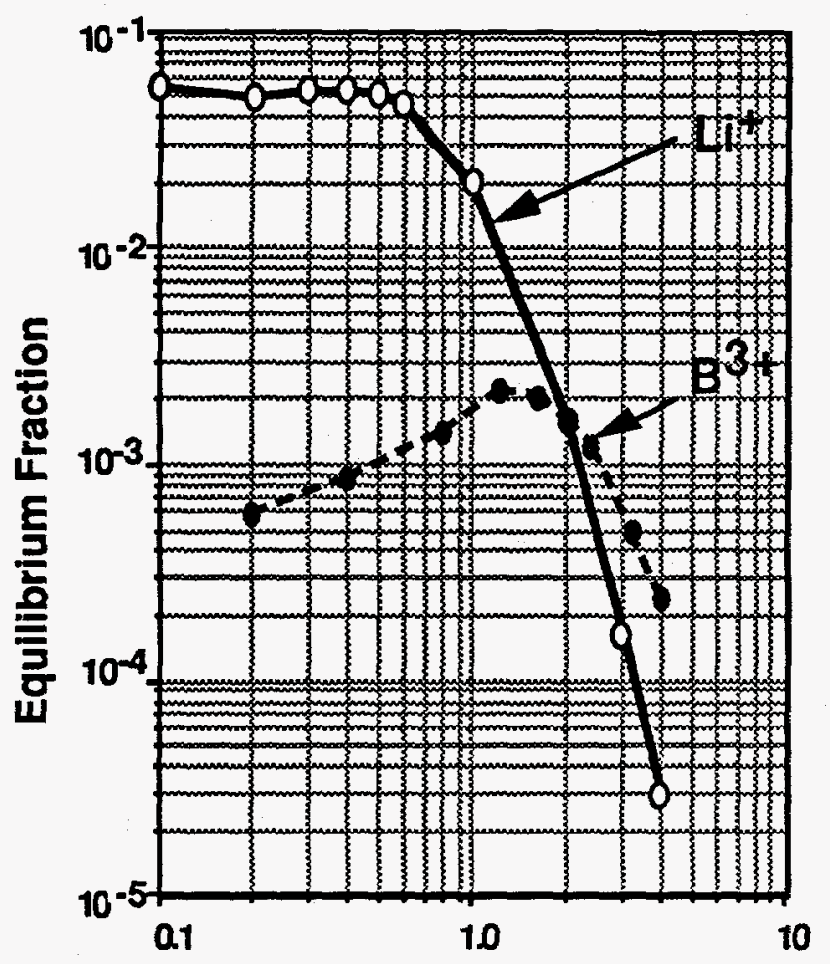

Alpha Energy (MeV)

Fig. 2 Calculated equilibrium fractions for Lithium and Boron. pellet as a result of decay of the electron temperature as well as to enhanced signal-tonoise ratio because the neutron background decays significantly faster than the confined alpha population. Even so, it is advantageous for PCX measurements to enhance the pellet penetration further and also to increase the signal level at higher alpha energies. For these reasons we investigated the use of boron pellets in place of lithium. As shown in Fig. 2 , for alpha energies above $\sim 2 \mathrm{MeV}$ the calculated equilibrium fraction for boron is significantly higher than for lithium. The higher heat of ablation energy of $5.3 \mathrm{eV} / \mathrm{atom}$ for boron compared with $1.6 \mathrm{eV} /$ atom for lithium should increase the pellet penetration. In practice, this gain is offset by lower pellet velocity from the injector due to the larger mass of boron relative to lithium. Nevertheless, an increased penetration for boron pellets ranging up to $20 \%(\sim 12 \mathrm{~cm})$ relative to lithium pellets of comparable mass is observed experimentally. In order to validate the use of boron, alpha energy spectra were compared for DT discharges using both lithium (\#86225) and boron (\# 86228,89,81) pellets as shown in Fig. 3. The boron spectra for the three discharges were normalized to account for small differences in the plasma conditions. As can be seen, the shapes of the alpha energy spectra for lithium and boron pellets are essentially the same. These measurements also confirm that for alpha particle energies above $\sim 2 \mathrm{MeV}$, boron pellets provide a more effective neutralization target that lithium pellets. Both pellet types are now routinely used in PCX diagnostic measurements.

Alpha spectra during the birth and slowing down phases are shown in Fig. 4. For the slowing down case ( $\# 86291, \mathrm{P}_{b}=15$ MW), the alpha distribution from 1-3.5 MeV was obtained using a boron pellet $200 \mathrm{~ms}$

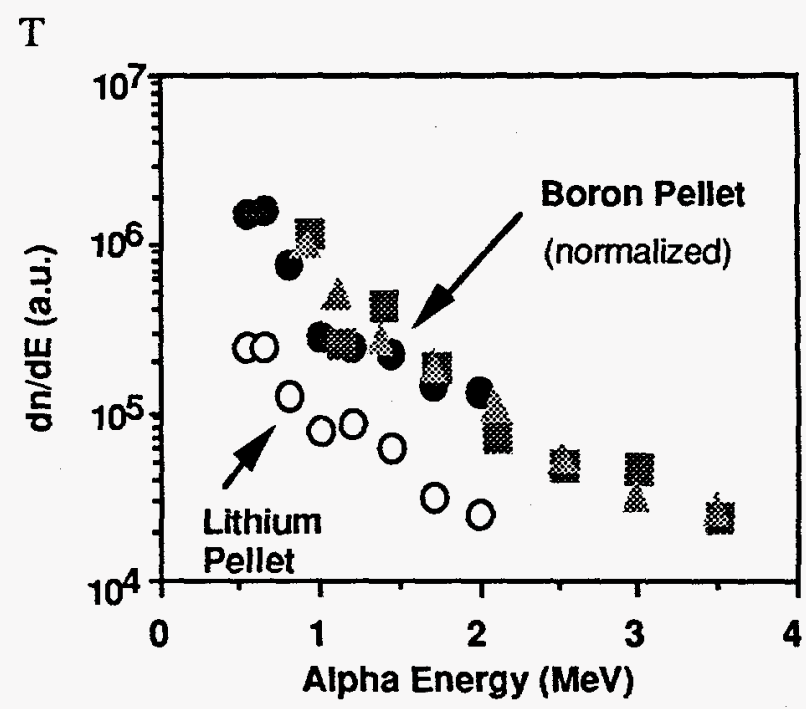

Fig. 3 Comparison of alpha spectra obtained using Boron and Lithium pellets. 


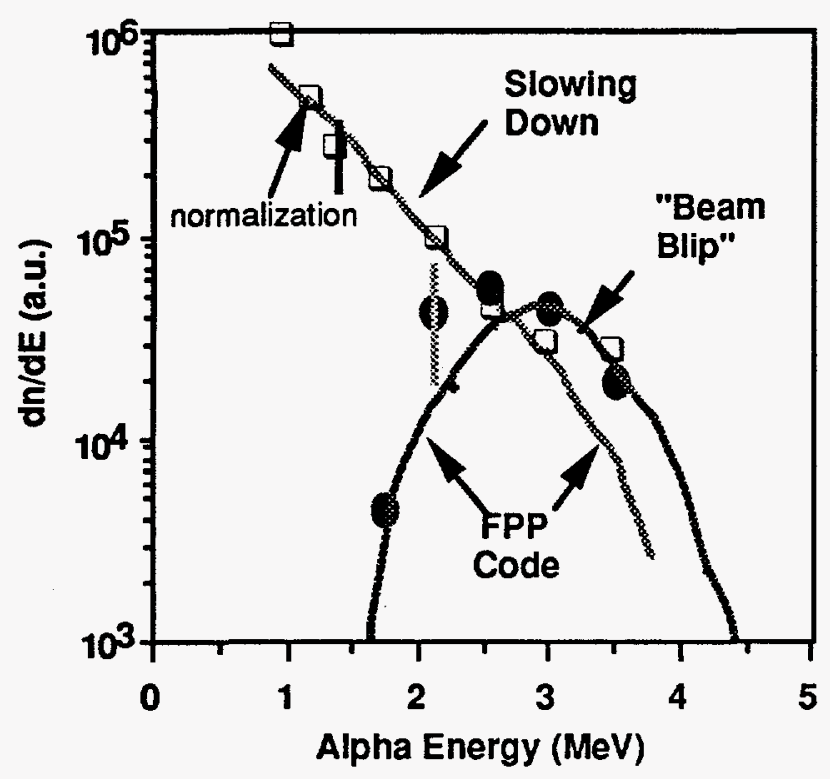

Fig. 4 Alpha energy spectra during birth and slowing down phases. after termination of a $1.0 \mathrm{~s}$ beam pulse while for the "beam blip" case (\#86299, $\mathrm{Pb}_{\mathrm{b}}=20 \mathrm{MW}$ ), the boron pellet was injected $20 \mathrm{~ms}$ after a $0.1 \mathrm{~s}$ beam pulse. Reasonable agreement is seen between the data and the FPP code results which include Doppler broadening of the alpha particle birth energy, $E_{\alpha}$, given by $\Delta E(k e V)=182\left(T_{\text {eff }}\right)^{0.5}$ where $T_{\text {eff }}=30$ $\mathrm{keV}$ is the effective temperature of the deuterium and tritium ions.

\subsection{Conclusions}

In the core of quiescent DT discharges in TFTR, good agreement is observed between the PCX measurements

of the confined, trapped alpha particles and tritons and TRANSP and FPP simulations. This indicates that alphas and tritons are well confined and slow down classically.

\section{Acknowledgments}

This work was supported by US DoE Contract DE-AC02-76-CHO-3073 and US DoE Grant DE-FG03-92ER54150. H. H. Duong is a General Atomics ORAU Fellow.

\section{References}

[1] R. K. Fisher, et al., Rev. Sci. Instrum. 63, 4499 (1992).

[2] R. K. Fisher, J. M. McChesney, P. B. Parks, et al., "Measurements of Fast Confined Alphas on TFTR," accepted for publication in Phys. Rev. Lett. (1995).

[3] M. P. Petrov, et al., "Studies of Confined Alphas Using the Pellet Charge Exchange Diagnostic on TFTR," submitted for publication in Nucl. Fusion (1995).

[4] A. B. Izvozchikov, et al., JET Joint Undertaking, Report JET-R(91) 12, (1991).

[5] S. S. Medley, et al., in Proc. 20th EPS Conf. on Controlled Fusion and Plasma Physics, Lisbon, 1993 (European Physical Society, Petit Lancy, 1993), Part III, p 1183.

[6] J. M. McChesney, et al., Rev. Sci. Instrum. 66, 348 (1995).

[7] R. V. Budny, Nucl. Fusion 34, 1247 (1994)

[8] N. N. Gorelenkov and S. V. Putvinskij, Sov. J. Plasma Phys. 15, 80 (1989)

[9] J. M. McChesney, et al. "Neutralization Fractions for Alpha Particles Interacting with Lithium Pellet Ablation Clouds," to be submitted to Nucl. Fusion, GA-A21958 (1995). 
Dr. F. Paoloni, Univ. of Wollongong, AUSTRALIA

Prof. R.C. Cross, Univ. of Sydney, AUSTRALIA

Plasma Research Lab. Australian Nat. Univ., AUSTRALIA

Prof. I.R. Jones, Flinders Univ, AUSTRALIA

Prof. F. Cap, Inst. for Theoretical Physics, AUSTRIA

Prof. M. Heindler, Institut tür Theoretische Physik, AUSTRIA

Prof. M. Goossens, Astronomisch InstituUt, BELGIUM

Ecole Royale Militaire, Lab. de Phy. Plasmas, BELGIUM

Commission-European, DG. XII-Fusion Prog., BELGIUM

Prof. R. Bouciqué, Rijksuniversiteit Gent, BELGIUM

Dr. P.H. Sakanaka, Instituto Fisica, BRAZIL

Prof. Dr. I.C. Nascimento, Instituto Fisica, Sao Paulo, BRAZIL Instituto Nacional De Pesquisas Espaciais-INPE, BRAZIL

Documents Office, Atomic Energy of Canada Lid., CANADA

Ms. M. Morin, CCFMTTokamak de Varennes, CANADA

Dr. M.P. Bachynski, MPB Technologies, Inc., CANADA

Dr. H.M. Skarsgard, Univ. of Saskatchewan, CANADA

Prof. J. Teichmann, Univ. of Montreal, CANADA

Prof. S.R. Sreenivasan, Univ, of Calgary, CANADA

Prof. R. Marchand, INRS-Energie et Materiaux, CANADA

Dr. R. Bolton, Centre canadien de fusion magnétique, CANADA

Dr. C.R. James, Univ. of Alberta, CANADA

Dr. P. Lukác, Komenského Universzita, CZECHO-SLOVAKIA

The Librarian, Culham Laboratory, ENGLAND

Library, R61, Rutherford Appleton Laboratory, ENGLAND

Mrs. S.A. Hutchinson, JET Library, ENGLAND

Dr. S.C. Sharma, Univ. of South Pacific, FIJI ISLANDS

P. Mähönen, Univ. of Heisinki, FINLAND

Prof. M.N. Bussac, Ecole Polytechnique., FRANCE

C. Mouttet, Lab. de Physique des Milieux lonisés, FRANCE

J. Radet, CEN/CADARACHE - Bat 506, FRANCE

Frof. E. Economou, Univ. of Crete, GREECE

Ms. C. Rinni, Univ. of loannina, GREECE

Preprint Library, Hungarian Academy of Sci., HUNGARY

Dr. B. DasGupta, Saha Inst. of Nuclear Physics, INDIA

Dr. P. Kaw, Inst. for Plasma Research, INDIA

Dr. P. Rosenau, Israel Inst of Technology, ISRAEL

Librarian, Intemational Center for Theo Physics, ITALY

Miss C. De Palo, Associazione EURATOM-ENEA, ITALY

Dr. G. Grosso, Istituto di Fisica del Plasma, ITALY

Prof. G. Rostangni, Istituto Gas Ionizzati Del Cnr, ITALY
Dr. H. Yamato, Toshiba Res \& Devel Center, JAPAN

Prof. I. Kawakami, Hiroshima Univ., JAPAN

Prof. K. Nishikawa, Hiroshima Univ., JAPAN

Librarian, Naka Fusion Research Establishme, it, JAERI, JAPAN

Director, Japan Atomic Energy Research Inst., JAPAN

Prof. S. Itoh, Kyushu Univ., JAPAN

Research Info. Crr., National Instit. for Fusion Scienć, JAPAN

Prof. S. Tanaka, Kyoto Univ., JAPAN

Library, Kyoto Univ., JAPAN

Prof. N. Inove, Univ. of Tokyo, JAPAN

Secretary, Plasma Section, Electrotectinical Lab., JAPAN

Dr. O. Mitarai, Kumamoto Inst. of Technology, JAPAN

Dr. G.S. Lee, Korea Basic Sci. Ctr., KOREA

J. Hyeon-Sook, Korea Atomic Energy Research Inst., KOREA

D.I. Choi, The Korea Adv. Inst. of Sa. \& Tech., KOREA

Leandro Melendez Lugo, Inst. Nac1. de Inves. Nucl, MEXICO

Prof. B.S. Liley, Univ. of Waikato, NEW ZEALAND

Inst of Physics, Chinese Acad Sci PEOPLE'S REP. OF CHINA

Library, Inst. of Plasma Physics, PEOPLE'S REP. OF CHINA

Tsinghua Univ. Library, PEOPLE'S REPUBLIC OF CHINA

Z. Li, S.W. Inst Physics, PEOPLE'S REPUBLIC OF CHINA

Prof. J.A.C. Cabral, Instituto Superior Tecnico, PORTUGAL

Prof. M.A. Hellberg, Univ. of Natal, S. AFAICA

Prof. D.E. Kim, Pohang Inst. of Sci. \& Tech., SO. KOREA

Prof. C.I.E.M.A.T, Fusion Division Library, SPAIN

Dr. L. Stenflo, Univ. of UMEA, SWEDEN

Library, Royal Inst. of Technology, SWEDEN

Prof. H. Withelmson, Chalmers Univ. of Tech., SWEDEN

Centre Phys. Des Plasmas, Ecole Polytech, SWITZERLAND

Bibliotheek, Inst. Voor Plasma-Fysica, THE NETHERLANDS

Asst. Prof. Dr. S. Cakir, Middle East Tech. Univ., TURKEY

Dr. V.A. Glukhikh,Sci. Res. Inst. Electrophys.I Apparatus, USSR

Dr. D.D. Ryutov, Siberian Branch of Academy of Sci., USSR

Dr. G.A. Eliseev, I.V. Kurchatov Inst., USSA

Librarian. The Ukr.SSR Academy of Sciences, USSR

Dr. L.M. Kovrizhnykh, Inst. of General Physics, USSR

Kernforschungsanlage $\mathrm{GmbH}$, Zentralbibliothek, W. GERMANY

Bibliothek, Inst. Für Plasmaforschung, W. GERMANY

Prof. K. Schindler, Ruhr-Universitát Bochum, W. GERMANY

Dr. F. Wagner, (ASDEX), Max-Planck-Institut, W. GERMANY

Librarian, Max-Planck-Institut, W. GERMANY 